\title{
PHYTOPHTHORA GENUS PATHOGENS ISOLATED FROM RHODODENDRONS IN LITHUANIA
}

\author{
Vilija Snieškienė, Antanina Stankevičienė \\ Kaunas Botanical Garden of Vytautas Magnus University, Lithuania \\ vilija.snieskiene@vdu.lt; antanina.stankeviciene@vdu.lt
}

\begin{abstract}
Rhododendron spp. plants were surveyed for Phytophthora infection in Lithuania during 2010 - 2016. This study aims to identify Phytophthora genus pathogen which infects rhododendrons in Lithuania. Samples were taken from young sick plants with visible infection symptoms. Soil sampling was performed from the rhizosphere of sick plants. DNA from soil and plant was tested for the presence of Phytophthora genus pathogens. Data showed positive results of Phytophthora genus specific probe during real-time PCR. All tested diseased leaves and soil samples have indicated Phytophthora sp. infection during Alert-LF® Phytophthora spp. analysis. The extracted DNA concentrations were not very high for Phytophthora species identification, but in most cases, it was high enough for further researches.

Key words: Phytophthora genus, Rhododedron, Lithuania.
\end{abstract}

\section{Introduction}

Rhododendrons are popular between professional and hobbyist abreast because of the great variety (ca. 12000 cultivars) and exceptional decorativeness (Malciūtė \& Naujalis, 2010). In Lithuania, rhododendrons were first introduced in the Vilnius Botanical Garden in 1814 (Skridaila, 1996). They were seldom cultivated in Lithuania until the second half of the 20th c. However, rhododendron plants have spread rapidly in Lithuania during the last thirty years (Navasaitis, 2004). Intolerance to the low and negative temperatures is one of the most important limiting factors for rhododendrons in Lithuania (Malciūtè, Naujalis, \& Šiaulienè, 2011). However, there is a shortage of information on the phytosanitary state of rhododendrons in Lithuania. Several fungi were isolated from rhododendrons in Lithuania, e.g. Erysiphe azaleae (U. Braun) U. Braun \& S. Takamatsu and Exobasidium japonicum Shirai causing rhododendron mildew and leaf blisters (Grigaliūnaite \& Pribušauskaitè, 2006; Lygis et al., 2010).

Phytophthora is plant pathogen genus belonging to Oomycetes which cause many plant species diseases. The first Phytophthora infections isolated from rhododendrons in other countries were documented ca. sixty years ago. At least ten Phytophthora species have been reported to be connected with Rhododendron roots, twig, and leaf pathogenesis worldwide: Phytophthora cactorum (Leb. and Cohn) Schröet., $P$. cinnamomi Rands, $P$. citricola Sawada, $P$. citrophthora (R.E. Smith and E.H. Smith) Leonian, $P$. cryptogea Pethybridge and Lafferty, $P$. gonapodyides (Petersen) Buisman, $P$. lateralis Tucker and Milbrath, $P$. megasperma Drechsler, $P$. nicotianae Breda de Haan, $P$. palmivora (Butler) Butler, $P$. ramorum Werres, De Cock \& Man in 't Veld, and $P$. syringae (Klebahn) Klebahn (Benson \& Jones, 1980; Erwin \& Ribeiro, 2005; Hoitink \& Schmitthenner, 1974; Nienhaus, 1960; Werres et al., 2001). P. ramorum first isolated from rhododendrons in Europe in 2002 (Orlikowski \& Szkuta, 2002; Morajelo \& Werres, 2002), the pathogen quickly spread to rhododendron nurseries and outdoor plantations in many European countries.

In Lithuania, the increasing number of rhododendrons infected by Phytophthora genus fungi has been reported (Table 1).

Phytophthora citricola was first isolated in Lithuania from drying rhododendron branches and top of twigs in 2002. It was isolated in Rhododendron

Table 1

Phytophthora species isolated from rhododendrons in Lithuania

\begin{tabular}{|c|c|c|c|c|}
\hline Rhododendron species & Year, authors & $\begin{array}{c}\text { Phytophthora } \\
\text { species }\end{array}$ & Location & Injuries \\
\hline $\begin{array}{l}\text { R. catawbiense } \\
\text { 'Grandiflorum' }\end{array}$ & 2002; Jovaišienè, Lane & P. citricola & Marijampolè district & $\begin{array}{l}\text { Branches and top } \\
\text { of twigs }\end{array}$ \\
\hline$R$. sp. & 2004; Jovaišienè, Lane & P. cactorum & $\begin{array}{l}\text { Kaunas, private } \\
\text { collection }\end{array}$ & Leaf and twigs \\
\hline$R$. sp. & 2004; Jovaišienė, Lane & P. cactorum & $\begin{array}{l}\text { Kaunas and Šiauliai } \\
\text { Botanical Garden }\end{array}$ & Leaf and twigs \\
\hline $\begin{array}{l}\text { R. catawbiense } \\
\text { 'Grandiflorum' }\end{array}$ & 2006; Jovaišienė, Lane & P. ramorum & Marijampolè district & Leaf and twigs \\
\hline
\end{tabular}


catawbiense 'Grandiflorum' in the Marijampolè district. Phytophthora cactorum was first isolated from the collection of rhododendrons in Kaunas and Šiauliai Botanical Gardens in 2004 (Jovaišienè \& Lane, 2006). P. ramorum was first isolated on fifty shrubs of Rhododendron catawbiense 'Grandiflorum' imported from Poland in the market centre of ornamental plants in Marijampolè district (Jovaišienè \& Lane, 2006). This species was described at first on oranges in Taiwan as a disease agent of brown rot in 1927 (Sawada, 1927). At present, $P$. citricola is spread in Europe and it is a disease agent of collar roots and stem canker in many economically important crops. Therefore, it is considered as an aggressive pathogen. The investigation on Phytophthora genus fungi started in Lithuania State Plant Protection Service in 2002. Several years later, the investigation has started in the Kaunas Botanical Garden of Vytautas Magnus University (VMU).

This study was aimed to identify Phytophthora genus pathogen infecting rhododendrons in Lithuania.

\section{Materials and Methods}

During 2010 - 2016 at least 6 samples were taken from each place which had sick Rhododendron. Samples were taken from young sick plants with visible infection symptoms, e.g., top and leaf wilting, leaf blotch and longitudinal twisting, leaf browning along the main vessel, and twig necrosis. Soil sampling was performed from the rhizosphere of sick plants. The sampling place are Kaunas Botanical Garden of Vytautas Magnus University and Alytus Park.

The taken samples are stored in the zip bags. They could be stored under $+4^{\circ} \mathrm{C}$ for a longer period. Leaves are washed with a tap water one time, branches and pieces of the stem are washed two times. Dry parts of plants are soaked into the tap water for 24 hours, washed two times. Samples, cut from a necrosis border are cut into $5 \times 5 \mathrm{~mm}$ pieces and put into at least four Petri dishes with growing medium under sterile environment (Jung, Blaschke, \& Neumann, 1996).

The soil bating is performed in a bath, which is poured with distilled water for $2 / 3$ of its volume. On the water surface fresh oak or rhododendron leaves are placed. The bath is left for $3-5$ days maintaining light/dark schedule and $18{ }^{\circ} \mathrm{C}$ temperature. The leaves are removed from the bath, washed out with tap water, divided into two parts and placed into the growing media. The isolation and identification of Phytophthora genus fungi is much more difficult in comparison to the other microscopic fungi (Werres et al., 2001). Therefore, various laboratory tests should be performed for the identification at the species level.

Malt extract agar (MEA) was used for the identification of Phytophthora species. MEA medium is produced with chloramphenicol. The prepared medium is autoclaved under $120{ }^{\circ} \mathrm{C}$ for $20 \mathrm{~min}$. (Erwin \& Ribeiro, 2005).

The incubation time was $1-3$ days in darkness maintaining $24{ }^{\circ} \mathrm{C}$. On the third day, Phytophthora hives are usually visible from the bottom side of the plate. Hives with medium pieces are transferred to water agar (WA) medium with capsicum or hemp seeds, which stimulate the formation of sporangia, which are formed within a few days (Jung, Blaschke, \& Neumann, 1996).

The Phytophthora genus fungi identification at the species level is performed according to descriptors (Erwin \& Ribeiro, 2005; Gallegly \& Hong, 2008).

Soil and plants samples before DNA extraction were tested for the presence of Phytophthora sp. using Alert-LF® Phytophthora spp. ELISA devices (Neogen Corporation). The soil probes were taken around roots from sick Rhododendron plants.

The DNA from leaves was extracted using NucleoSpin ${ }^{\circledR}$ Plant II kit (Mecherey-Nagel). The soil samples were prebaited four days in a PeaBroth PARP media and DNA was extracted using PowerSoil ${ }^{\circledR}$ DNA Isolation Kit (MoBio). The PB-PARP (1000ml) was prepared by autoclaving $100 \mathrm{~g}$ of frozen peas and using the following amendments: $0.25 \mathrm{~g}$. of ampicillin, $0.01 \mathrm{~g}$ of pimaricin, $0.01 \mathrm{~g}$. of rifampicin, 0.05 g. of hymexazol, and 0.05 g. of PCNB. Extracted DNA quality was checked using spectrophotometer NanoDrop (Thermo Fisher Scientific) and electrophoresis on TAE buffer. The presence of Phytophthora genus DNA in samples was confirmed using real time PCR (tests were performed at the Polish Forest Research Institute) (Vitas et al., 2012).

\section{Results and Discussion}

In 2013 - 2015 we found sick rhododendrons in Kaunas Botanical Garden nursery and Alytus Park. The common symptoms of infected rhododendrons top and leaf wilting, leaf spots and twig necrosis.

All ELISA tests with soil and plants samples were positive for Phytophthora spp. infection.

DNA extracted from soil and plant (leaves) was tested for Phytophthora genus pathogens. All analyzed samples showed positive results of Phytophthora genus specific probe during real-time PCR.

The DNA concentrations of the extracted leaf samples varied from 2.75 to $5.10 \mathrm{ng} \mathrm{ml}^{-1}$ (Table 2). The DNA concentrations from soil samples were from 5.78 to $10.02 \mathrm{ng} \mathrm{ml}^{-1}$. The ratio of sample absorbance at 260 and $280 \mathrm{~nm}$ varied from 1.08 to 2.90 and the ratio of sample absorbance at 260 and 230 varied from 0.50 to 1.41 . The results above show the positive use of commercial kits for DNA extraction from symptomatic leaves and soil.

All 6 samples were recognized by Phytophthoraspecific probe. Based on this all samples can be 


\section{DNA concentrations, quality characteristics of extracted samples and results of Phytophthora genus specific real time PCR}

\begin{tabular}{|l|l|l|c|c|c|c|}
\hline $\begin{array}{c}\text { Rhododendron } \\
\text { species }\end{array}$ & \multicolumn{1}{|c|}{ City, place } & $\begin{array}{c}\text { Part of the } \\
\text { plant or } \\
\text { soil }\end{array}$ & $\begin{array}{c}\text { DNA } \\
{\left[\mathrm{ng} \mathrm{m}^{-1}\right]}\end{array}$ & $\begin{array}{c}\text { Ratio of } \\
\text { absorbance } \\
260 / 280\end{array}$ & $\begin{array}{c}\text { Ratio of } \\
\text { absorbance } \\
260 / 230\end{array}$ & Ct \\
\hline R. catawbiense & Kaunas Botanical Garden & leaves & 2.75 & 2.42 & 0.92 & 17.70 \\
\hline R. sp. & Alytus Park & leaves & 5.10 & 1.16 & 0.52 & 24.50 \\
\hline R. catawbiense & Kaunas Botanical Garden & soil & 6.96 & 1.57 & 0.50 & 25.07 \\
\hline R. catawbiense & Kaunas Botanical Garden & soil & 10.02 & 1.83 & 0.79 & 25.91 \\
\hline R. catawbiense & Kaunas Botanical Garden & soil & 7.11 & 1.08 & 0.75 & 20.63 \\
\hline R. sp. & Kaunas Botanical Garden & soil & 5.78 & 2.90 & 1.41 & 25.62 \\
\hline
\end{tabular}

considered as containing Phytophthora DNA. The amount of DNA in the sample is expressed by the $\mathrm{Ct}$ value. Lower value means that more Phytophthora DNA is present in the sample. The lowest $(\mathrm{Ct}=25.91)$ amount of pathogen DNA was found in soil of Kaunas Botanical Garden rhododendron nursery (Table 2).

The extracted DNA concentrations were not very high for Phytophthora species identification, but in most cases, it was high enough for further researches.

Phytophthora genus pathogens spread is favoured by environmental conditions: soil flooding and excess moisture, droughts, and temperature extremes (Erwin \& Ribeiro, 2005). Also, an intensive international trade of living plants accelerates the spreading of alien species over long distances (Jung et al., 2005).

\section{Conclusions}

1. The common symptoms of Phytophthora infected rhododendrons - top and leaf wilting, leaf spots and twig necrosis.

2. All tested diseased leaves and soil samples have indicated Phytophthora sp. infection during AlertLF® Phytophthora spp. analysis.

3. All tested samples can be considered as containing Phytophthora DNA. The extracted DNA concentrations were not very high for Phytophthora species identification, but in most cases, it was high enough for further researches.

\section{References}

1. Benson, D.M., \& Jones, R.K. (1980). Etiology of rhododendron dieback caused by four species of Phytophthora. Plant Dis. 64, 687-691. DOI: 10.1094/PD-64-687.

2. Erwin, D.C., \& Ribeiro, O.K. (2005). Phytophthora diseases worldwide. St. Paul: APS Press.

3. Gallegy, M., \& Hong, C. (2008). Phytophthora: identifying species by morphology and DNA fingerprint. St. Paul, Mn.: American Phytopathological Society Press.

4. Grigaliūnaitè, B., \& Pribušauskaite, V. (2006). Erysiphe azaleae on Rhododendron in Lithuania. Botanica Lithuanica. 12(2), 127-129.

5. Hoitink, H.A.J., \& Schmitthenner, A.F. (1974). Relative prevalence and virulence of Phytophthora species involved in rhododendron root rot. Phytopathology. 64, 1371-1374. DOI: 10.1094/Phyto-64-1371.

6. Jovaišienè, Z., \& Lane, C. (2006). First report of Phytophthora cactorum in Lithuania. Botanica Lithuanica. 12(3), 197-199.

7. Jung, T., Blaschke, H., \& Naumann, P. (1996). Isolation, identification and pathogenicity of Phytophthora species from declining oak stands. European Journal of Forest Pathology. 26, 253-272. DOI: 10.1111/ j.1439-0329.1996.tb00846.x.

8. Jung, T., Hudler, G.W., Jensen-Tracy, S.L., Griffits, H.M., Fleischmann, F., \& Osswald, W. (2005). Involvment of Phytophthora species in the decline of European beech in Europe and the USA. Mycologist. 19, 159-166. DOI: 10.1017/S0269915X05004052.

9. Lygis, V., Grigaliūnaitė, B., Matelis, A., \& Pribušauskaitė, V. (2010). Exobasidium japonicum-rododendrų pūslialigès sukèlèjas (Exobasidium japonicum - a causal agent of Rhododendron leaf blisters). Scripta Horti Botanici Universitatis Vytauti Magni. 14, 105-112. (in Lithuanian).

10. Malciūtè, A., \& Naujalis, J.R. (2010). Some relevant problems of Rhododendron introduction in Lithuania. Botanica Lithuanica. 16(2-3), 69-73. 
11. Malciūtė, A., Naujalis, J.R., \& Šiaulienè, I. (2011). The seasonal development characteristics of different taxa and cultivars of rhododendrons in Northern Lithuania. 2. Flowering peculiarities. Žemdirbyste். 98(1), 81-92.

12. Moralejo, E., \& Werres, S. (2002). First report of Phytophthora ramorum on Rhododendron in Spain. Plant Dis. 86, 1052. DOI: 10.1094/PDIS.2002.86.9.1052A.

13. Navasaitis, M. (2004). Dendrologija (Dedrologia). Vilnius: Vaga. (in Lithuanian).

14. Nienhaus, F. (1960). Das Wirtsspektrum von Phytophthora cactorum (Leb. et Cohn) Schroet. Journal of Phytopathology. 38(1), 33-68. DOI: 10.1111/j.1439-0434.1960.tb01893.x.

15. Orlikowski, L.B., \& Szkuta, G. (2002). First record of Phytophthora ramorum in Poland. Phytopathologia Polonica. 25, 69-79.

16. Sawada, (1927). Descriptive catalogue of the Formosan fungi. III. Rep. Dep. Agric. Gov. Res. Inst. Formosa Bull. 27, 1-62.

17. Skridaila, A. (1996). Vilniaus universiteto Botanikos sodas 1782-1842 metais ir pirmieji moksliniai šaltiniai apie augalų introdukciją Lietuvoje (Botanical Garden of Vilnius University in 1782-1842 and the first scientific sources about the introduction of plants in Lithuania). Dendrologia Lithuaniae. 3, 50-74. (in Lithuanian).

18. Vitas, A., Oszako, T., Nowakowska, J.A., Sikora, K., \& Stankevičienè, A. (2012). First records of Phytophthora spp. based on DNA analysis in Lithuania. Folia Forestalia Polonica. 54(1), 25-31. DOI: 10.5281/zenodo.30881.

19. Werres, S., Marwitz, R., Man In't Veld, W.A., De Cock, A.W.A.M., Bonats, P.J.M., De Weerdt, M., Themann, K., Ilieva, E., \& Baayen, R.P. (2001). Phytophthora ramorum sp. nov., a new pathogen on Rhododendron and Viburnum. Mycol. Res. 105(10), 1155-1165. 